\title{
カルサイトの炭素・酸素同位体比から見た 野島断層浅部破砕帯のシール過程の解明
}

\author{
新 井崇 史* 塚 原弘昭**森清寿 朗*** \\ Sealing Process with Calcite in the Nojima Active Fault Zone \\ Revealed from Isotope Analysis of Calcite
}

Takashi ARAI *, Hiroaki TSUKAHARA** and Toshiro MORIKIYO***

\begin{abstract}
The Nojima fault appeared on the surface in the northern part of Awaji Island, central Japan as a result of the Hyogo-ken Nanbu earthquake (1995, $M=7.2$ ). Active fault drilling was performed by the Disaster Prevention Research Institute (DPRI), Kyoto University, and core samples were retrieved from 1410 to $1710 \mathrm{~m}$, which were composed of intact and fractured granodiorites. We obtained calcite samples and gas samples from the vein in marginal fracture and non-fracture zones. We analyzed the carbon and oxygen isotope ratios of calcite and carbon dioxide to investigate the characteristic isotope ratios of fluids in the active fault zone, to estimate the origins of fluids, and to determine the sealing process of fractures. The analyzed values of carbon and oxygen isotope ratios of calcite were -10.3 to $-7.2 \%, 18$ to $23 \%$, respectively, and carbon isotope ratios of $\mathrm{CO}_{2}$ were -21 to $-17 \%$. If carbon isotope ratios of calcite were at equilibrium with those of $\mathrm{CO}_{2}$, the precipitation temperature of calcite is calculated to be 30 to $50^{\circ} \mathrm{C}$. This temperature is consistent with the present temperature of the depth where drilling cores were retrieved. Oxygen isotope ratios of $\mathrm{H}_{2} \mathrm{O}$ that, precipitated calcite were calculated to be -1.8 to $-5.5 \%$. These values indicate calcite were precipitated from mixed fluids of sea water and meteoric water. Therefore, the marginal fracture zone of the Nojima fault was sealed with calcite, which was generated from mixing of sea water and meteoric water in situ.
\end{abstract}

Key words: earthquake, isotopic geochemistry, fault fluids, sealing process, Nojima Fault, isotope geothermometer

キーワード: 地震, 同位体地球化学, 断層流体, シール過程, 野島断層, 同位体地質温度計

\footnotetext{
* 信州大学理学部物質循環学科（現, 産業技術総合研究所）

** 信州大学理学部物質循環学科

*** 信州大学理学部地質学科

* Department of Environmental Sciences, Faculty of Science, Shinshu University (Present address: National Institute of Advances Industrial Science and Technology. AIST)

** Department of Environmental Sciences, Faculty of Science, Shinshu University

*** Department of Geology, Facurty of Science, Shinshu University
} 


\section{I.はじめに}

断層带における岩石一流体相互作用において主 要な役割を果たす流体化学成分の 1 つに炭酸ガス $\left(\mathrm{CO}_{2}\right)$ がある。 $\mathrm{CO}_{2}$ は, 地下水中に溶け込むと, 水 素イオン $\left(\mathrm{H}^{+}\right)$と重炭酸イオン $\left(\mathrm{HCO}^{3-}\right)$ に解離 する。水素イオンは岩石を溶解するが, 重炭酸イ オンはカルシウムイオン $\left(\mathrm{Ca}^{2+}\right)$ と反応し，カル サイト $\left(\mathrm{CaCO}_{3}\right)$ を形成する。このように形成さ れたカルサイトは，断層破砕帯をシールする鉱物 として，断層岩中に見うけられることが多い。 よって, 水に溶存する $\mathrm{CO}_{2}$ やカルサイト形成が, 地震後の断層の性質やシーリングによる断層回復 過程に与える影響は大きいと考えられる。

1995 年兵庫県南部地震 $(M=7.2)$ の際に滑っ た野島断層が露出している兵庫県淡路島北淡町
において, 京都大学防災研究所により媣度約 $1700 \mathrm{~m}$ のボーリング孔（DPRI $1800 \mathrm{~m}$ 孔）が掘 削された (Ando, 2001)（図 1)。この掘削は，地 表断層の東側, 水平距離にして約 $450 \mathrm{~m}$ の地点か ら深度約 $1800 \mathrm{~m}$ の断層上盤側破砕带に向けて実 施され，同時に，掘削深度 $1250 \sim 1710 \mathrm{~m}$ 間のコ アが連続的に回収された（図 2 )。

その際, 新井ほか (1998), Arai et al. (2001) は, 掘削直後の野島断層ボーリングコア（1410 $1710 \mathrm{~m}$ 間）から地中ガスを採取し，これを分析し た結果，断層帯内から採取されたガスの主成分の 1 つが $\mathrm{CO}_{2}$ であることを報告した。一方，破砕帯 の多くにカルサイト $\left(\mathrm{CaCO}_{3}\right)$ が脈状に多数存 在し，破砕帯をセメンチングしている観察例も， 多数報告されている（例えば, Fujimoto et al., 2001)。

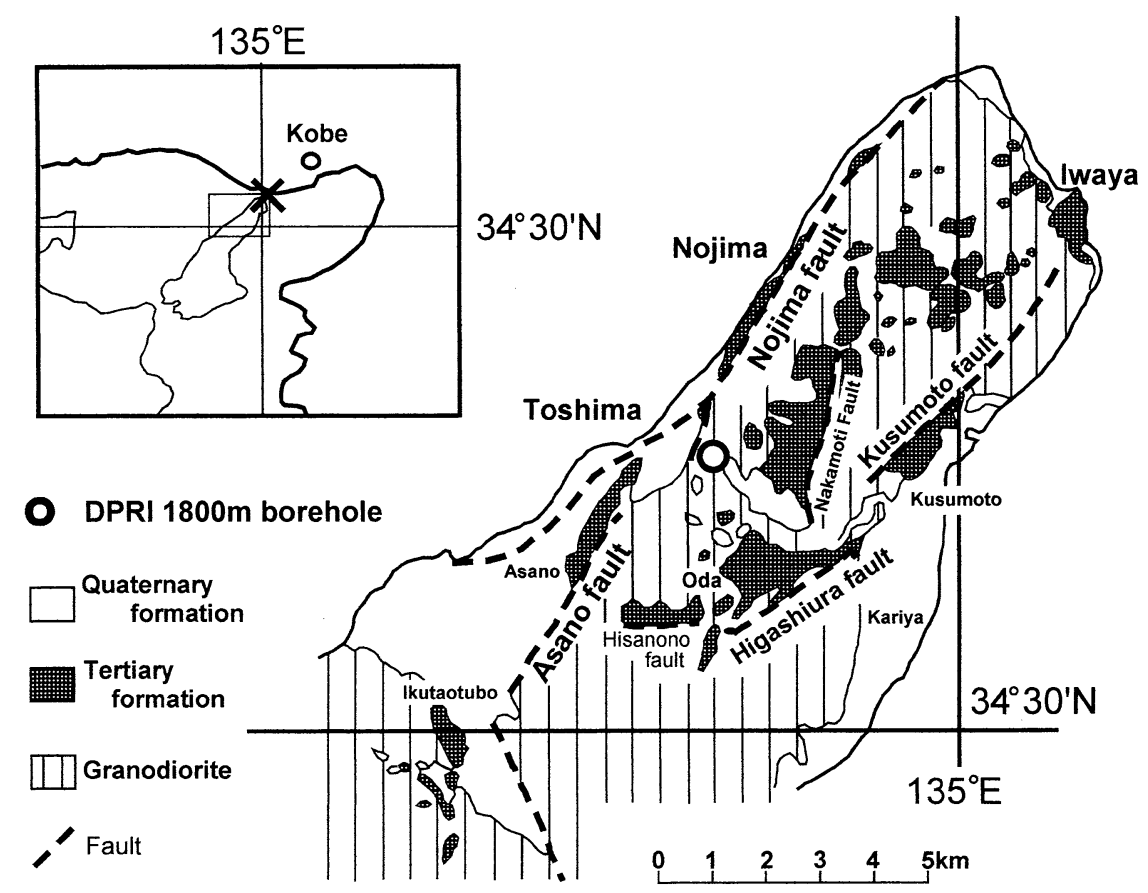

図 1 淡路島北部の DPRI $1800 \mathrm{~m}$ 孔の掘削地点（白丸印）および周辺地質図（水野ほ か, 1990 に掘削地点を加筆).

地表活断層は点線で示されている.

Fig. 1 Location of DPRI $1800 \mathrm{~m}$ drill site (open circle) with simplified geologic map (from Mizuno et al., 1990) of northern part of Awaji Island.

Surface trace of active faults is shown by dotted lines. 


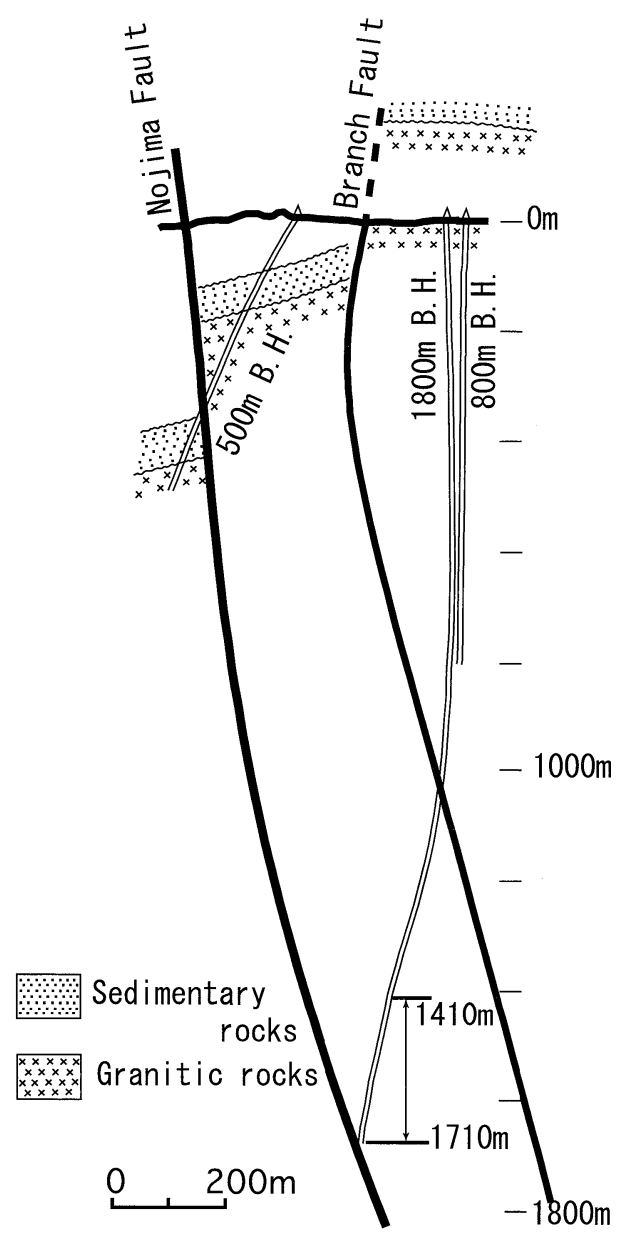

図2 京都大学防災研究所によって実施された $1800,800,500 \mathrm{~m}$ の各掘削孔と断層の関係 を示す断面図.

ガスおよびカルサイトは, $1800 \mathrm{~m}$ 孔の掘削深度 1410 ～ $1710 \mathrm{~m}$ において採取された.

Fig. 2 Vertical cross-section and the positions of three boreholes of the Disaster Prevention of Research Institute and Nojima fault.

Gas and calcite samples were extracted from core specimens obtained at drilling depths between $1410 \mathrm{~m}$ and $1710 \mathrm{~m}$ in $1800 \mathrm{~m}$ boreholes.

本論では, 野島断層破砕帯を一例として, 地中 ガス中の $\mathrm{CO}_{2}$ の炭素同位体比 $\left(\delta{ }^{13} \mathrm{C}\left[\mathrm{CO}_{2}\right]\right)$ と 脈状に産するカルサイトの炭素・酸素同位体比 $\left(\delta{ }^{13} \mathrm{C}\left[\mathrm{CaCO}_{3}\right], \delta{ }^{18} \mathrm{O}\left[\mathrm{CaCO}_{3}\right]\right)$ を測定し，その 特徵を明らかにした。これらの同位体比は, 断層
内流体の起源の情報を保持しているだけでなく， 仮に同位体平衡に達していれば，これらを比較す ることで断層带のシール温度の推定にも有用とな る。

Tadokoro et al.（2000）は，S 波偏向異方性の 時間変化から断層深部が地震発生から 3 年以内に 固着していた可能性を指摘している。これらの地 震波観測結果から得られる固着とは, 必ずしも強 度の回復ではなくともよい。亀裂が物質で充填さ れれば地震波にとっては固着が完了したことにな る。よって，断層帯のシール機構を明らかにする 上でこのような議論は欠かせない。また, 小林ほ か（1999）は, DPRI $1800 \mathrm{~m}$ 孔の全長にわたる コア観察を行った結果, 主スリップゾーンに相当 する断層がウジ帯が認められなかったので，ボー リング孔は主スリップゾーンに到達しておらず, コアとして採取された部分は破砕帯外縁部に当た ると見なした。しかし，小林ほか（1999）も指摘 しているように，このような上盤側破砕帯外縁部 の構造は, 断層帯の透水特性を考察する上でも重 要であり, 流体の挙動に大きな影響を与えている と考えられる。

\section{II. 測 定 方法}

ガス抽出は, 回収されたばかりのコアから真空 ポンプを利用することにより採取した。詳細は新 井ほか（1998）を参考にしていただきたい。ガス 濃度分析は, ガスクロマトグラフ（大倉社製ガ スクロマトグラフ Model-802T) で測定した。 ガスクロマトグラフの $\mathrm{CO}_{2}$ 濃度の分析誤差は, $\pm 0.5 \mathrm{ppm}$ 以内である。 $\mathrm{CO}_{2}$ の炭素同位体比 $\left(\delta{ }^{13} \mathrm{C}\right)$ は東京大学理学部地殸化学実験施設の irmGC/C/MS（ガスクロマトグラフと燃焼炉と同 位体質量分析計をオンラインで接続した装置)（角 皆, 1997）を用いて分析した（測定䛊差は $\pm 1 \%$ ）。

一方，カルサイトは脈状に産するものを鉄釘で 直接削りだした。これを，めのう乳鉢を使って粉 末状にした後，粉末 X 線回折装置 (XRD) により 鑑定をおこない，カルサイトを多く含有するサン プルを選定し，分析用試料として使用した。試料 約 $0.5 \mathrm{mg}$ を次式のように $100 \%$ のリン酸と反応さ 


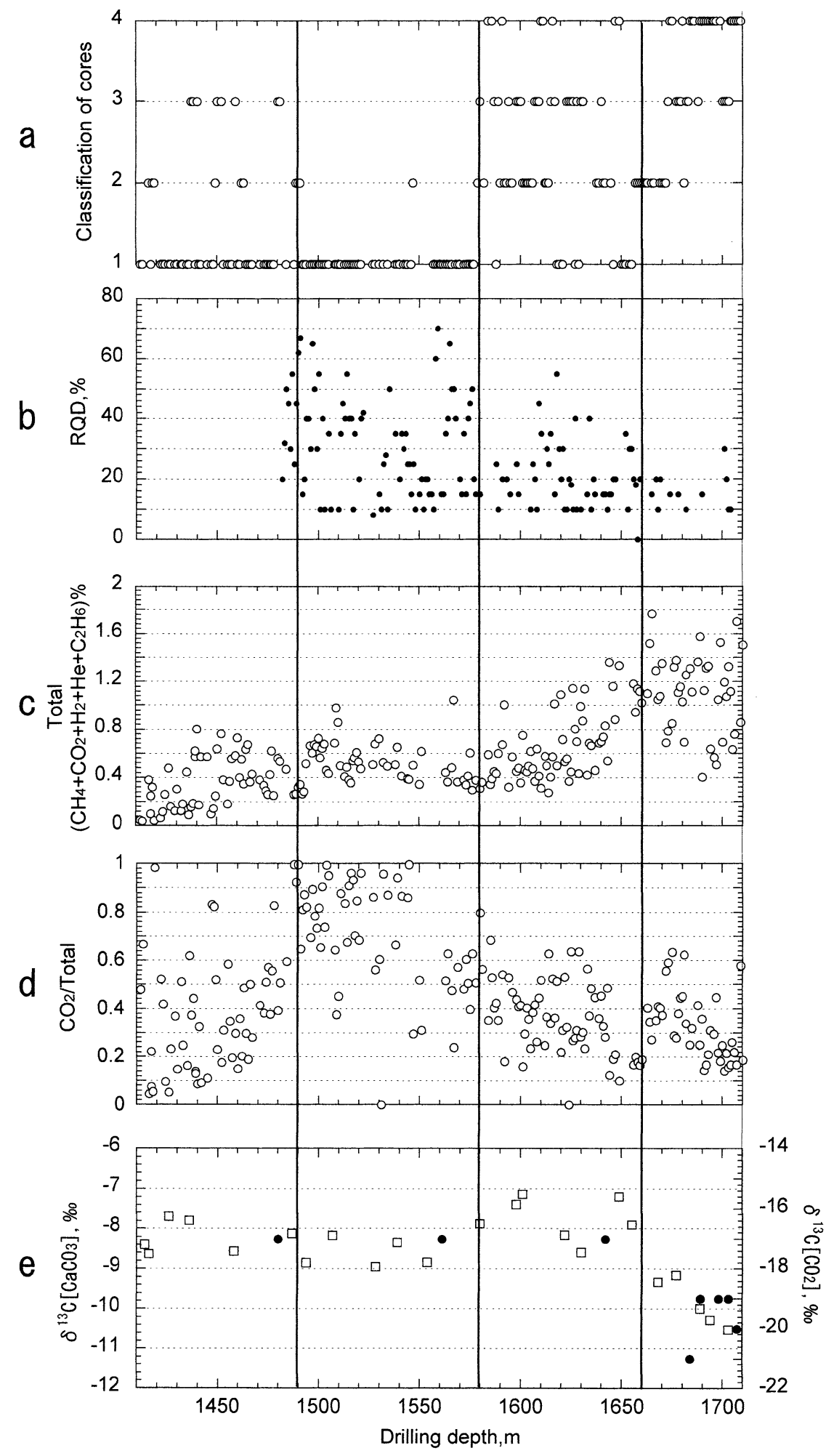


せ，発生した $\mathrm{CO}_{2}$ を抽出し，これを $\mathrm{CaCO}_{3}$ の炭 素・酸素同位体組成の測定に用いた（McCrea， 1950)。

$$
2 \mathrm{H}_{3} \mathrm{PO}_{4}+3 \mathrm{CaCO}_{3} \rightarrow \mathrm{Ca}_{3}\left(\mathrm{PO}_{4}\right)_{2}+3 \mathrm{CO}_{2}+3 \mathrm{H}_{2} \mathrm{O}
$$

リン酸との反応で抽出される $\mathrm{CO}_{2}$ とカルサイト では，温度に依存して酸素同位体比が異なる。こ のため, $25^{\circ} \mathrm{C}$ で反応させ, $\mathrm{CO}_{2}-\mathrm{CaCO}_{3}$ 間の同位 体分別係数 $\alpha$ の值として, Sharma and Clayton （1965）の值，1.01025を用いた。

ただし，亀裂群を充填する炭酸塩鉱物には主要 鉱物カルサイト $\left(\mathrm{CaCO}_{3}\right)$ の他に, シデライト $\left(\mathrm{FeCO}_{3}\right)$, ドロマイト $\left[\mathrm{Ca}(\mathrm{Mg}, \mathrm{Fe}, \mathrm{Mn})\left(\mathrm{CO}_{3}\right)_{2}\right]$ も少量存在する。反応に要する時間は鉱物種によ り異なり， $25^{\circ} \mathrm{C}$ でカルサイトは 1 時間，ドロマイ トは 3 日間, シデライトについては, $50^{\circ} \mathrm{C}$ で 1 週 間要する（Epstein et al., 1964）。そこで，25ㄷ で反応開始後, 1 時間までに抽出された $\mathrm{CO}_{2}$ の炭 素・酸素同位体比を測定し，ドロマイト，シデラ イトの影響を受けないようにした。同位体比の 測定は信州大学理学部地質学教室の MAT250 質量分析計を用いた。測定值は，標準物質からの 千分偏差 $\delta$ 值 $(\%)$ で表示する。炭素同位体比に 関しては, PDB (Peedee 層産 Belemnite) を 基準とし, 酸素同位体比に関しては, 標準平均 海水（SMOW）を基準とした。測定誤差は, $\delta{ }^{13} \mathrm{C}\left[\mathrm{CaCO}_{3}\right]$ が $0.1 \%$ 以内, $\delta{ }^{18} \mathrm{O}\left[\mathrm{CaCO}_{3}\right]$ が士0.3\%以内であった。

\section{III. 測 定 結果}

\section{1）コア試料の破砕度の深度による変化とカル サイト脈傾斜角との関係について}

同位体比㧍よびガス濃度の深度分布と比較する ため, ガスを採取した岩石コア試料 $(10 \sim 20 \mathrm{~cm})$ を肉眼で観察して，岩石試料の外見を次のように 簡易的に区分した（図 3a）。

1 ：肉眼で観察できるほどの微小亀裂（幅 $0.5 \mathrm{~mm}$ 以下) が見うけられるものの，破砕をほと んど受けていない比較的新鮮なコア。

2 ：若干破砕作用を受けることにより，白濁し て見えるが，岩石の組織は明瞭であるコア。

3 : コア全体が白色を呈し, 岩石の組織がやや 不明瞭である。 2 との違いは，岩石の一部または 全体が破砕作用を受け，礫状もしくは砂状を呈す。

4：一部または多くが灰色を呈し, 粘土状に なっているコア。

これらと比較するために，掘削深度 $1470 \mathrm{~m}$ 以 深における RQD (Rock Quality Designation) 值を計測した。RQD 值は， $1 \mathrm{~m}$ 中に含まれる $10 \mathrm{~cm}$ 以上の棒状コア総計長の割合を示した值で, 岩盤の不連続性（割れ目の多さ）を示す指数とし て用いられる（図 3b）。

両グラフから 1490 ～ $1580 \mathrm{~m}$ で破砕の程度が最 も低いこと, $1660 \mathrm{~m}$ 以樑で最も破砕が進行して いることがわかる。

一方，120 個のカルサイト脈の傾斜角を測定し

$\mathrm{a}$ ：コアの破砕の程度：1〜4(詳細は本文参照).

$\mathrm{b}: 1 \mathrm{~m}$ 中に含まれる $10 \mathrm{~cm}$ 以上の棒状コア総計長の割合を示した值（RQD 值）.

c : $\mathrm{CH}_{4}, \mathrm{CO}_{2}, \mathrm{H}_{2}, \mathrm{C}_{2} \mathrm{H}_{6}, \mathrm{He}$ ガス濃度の総和.

$\mathrm{d}: \mathrm{c}$ のガス濃度の総和に対する $\mathrm{CO}_{2}$ 濃度の割合.

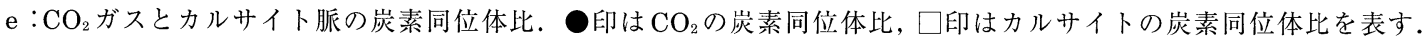
また，コアの破砕の程度および RQD 值から $1410 〜 1710 \mathrm{~m}$ 間を直線で 4 区間に区分した $(1490 \mathrm{~m}, 1580 \mathrm{~m}, 1660 \mathrm{~m})$.

Fig. 3 Variations in gas concentration and carbon isotope ratio with depth.

a : Degree of fragmentation of core specimens. Weak to strong : 1 to 4 (see text).

$\mathrm{b}$ : Percentage in length of core specimens longer than $10 \mathrm{~cm}$ in $1 \mathrm{~m}$.

c : Total gas concentration of $\left(\mathrm{CH}_{4}+\mathrm{CO}_{2}+\mathrm{H}_{2}+\mathrm{C}_{2} \mathrm{H}_{6}+\mathrm{He}\right)$ in ppm.

$\mathrm{d}$ : Concentration of $\mathrm{CO}_{2}$ relative to the total gas concentration.

e : Carbon isotope ratios of $\mathrm{CO}_{2}$ extracted from core specimens and of $\mathrm{CaCO}_{3}$ from carbonate veins. Closed circle and open square indicate carbon isotope ratios of $\mathrm{CO}_{2}$ and $\mathrm{CaCO}_{3}$, respectively.

We divided them into four sections from the results of values for fragmentation and RQD (solid lines). 
表 1 同位体比測定用に採取した各深度に占めるカルサイト脈の本数およびその傾斜角の割合.

Table 1 Numbers and rate for dip of calcite veins with depth.

\begin{tabular}{rrrrrrr}
\hline & $0-30^{\circ}$ & Number of veins & $30-60^{\circ}$ & Number of veins & $60-91^{\circ}$ & Number of veins \\
\hline $1410-1490 \mathrm{~m}$ & $42.1 \%$ & 8 & $15.8 \%$ & 3 & $42.1 \%$ & 8 \\
$1490-1580 \mathrm{~m}$ & $42.3 \%$ & 11 & $26.9 \%$ & 7 & $30.8 \%$ & 8 \\
$1580-1660 \mathrm{~m}$ & $9.5 \%$ & 2 & $19.0 \%$ & 4 & $71.4 \%$ & 15 \\
$1660-1710 \mathrm{~m}$ & $5.9 \%$ & 1 & $35.3 \%$ & 6 & $58.8 \%$ & 10 \\
\hline
\end{tabular}
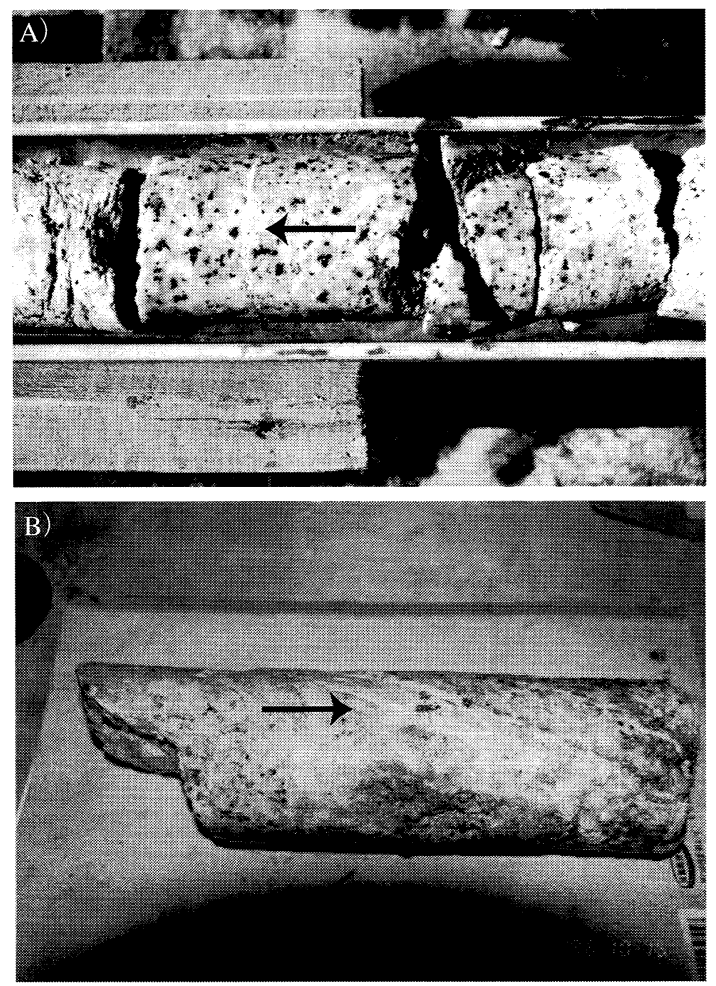

$5 \mathrm{~cm}$

図 $41538 \mathrm{~m}$ と $1640 \mathrm{~m}$ における脈の写真の一例.

A）比較的破砕を受けていない個所では，低角で純 粋なカルサイト脈が卓越する。

B）破砕を受けている個所ではカルサイト脈は高角 であり，花崗閃緑岩の岩片を含むことが多い.

Fig. 4 Photos of veins at depths of $1538 \mathrm{~m}$ and $1640 \mathrm{~m}$.

A) In the non-fractured zone, calcite veins at a low angle dominated.

B) In the fracture zone, calcite veins at a high angle dominated. They often contain fragments of granodiorite.
た結果，1460～ $1560 \mathrm{~m}$ の岩石が破砕の影響をほ ぼ受けていない深度では，低角 $\left(0 \sim 30^{\circ}\right)$ のカ ルサイト脈が卓越しており，その他の深度では高 角 $\left(60 \sim 90^{\circ}\right)$ のカルサイト脈が卓越している ことがわかった（表 1, 図 4）。ただし，1410～ $1710 \mathrm{~m}$ 間の孔井傾斜角は $80^{\circ} \mathrm{NW}$ なで, 亀裂の 傾斜角には最大 $\pm 10^{\circ}$ の誤差があると考えられる。 Murata et al.（2001）によると, 野島断層の傾斜 角は， $83^{\circ} \mathrm{SE}$ と高角である。破砕の進行した深度 で高角のカルサイト脈が多いことは, 断層運動と 鉱物脈形成に明確な相関があることを示している。

\section{2) 二酸化炭素濃度とその炭素同位体比の深度}

\section{による変化とその起源について}

新井ほか (1998), Arai et al. (2001) によれ ば，コア試料において，岩石が比較的破砕を受け ていない場所では，岩石に含有されるガスの主成 分は $\mathrm{CO}_{2}$ である（図 $3 \mathrm{~d} ） 。$ 図 $3 \mathrm{~d}$ は, 大気主成分 以外のガス濃度の総和 $\left(\mathrm{CH}_{4}+\mathrm{CO}_{2}+\mathrm{H}_{2}+\mathrm{C}_{2} \mathrm{H}_{6}\right.$ $+\mathrm{He}$ ) (図 $3 \mathrm{c}$ に示す) 中に $\mathrm{CO}_{2}$ が占める割合を 深度に対してプロットし，その変化を示している。 図 $3 \mathrm{a}$ と図 $3 \mathrm{~d}$ とを比較すると, 破砕度の低い場所 で $\mathrm{CO}_{2}$ 濃度が高いことがわかる。

一方, $\mathrm{CO}_{2}$ の起源を特定するために $\mathrm{CO}_{2}$ の炭素 同位体比 $\left(\delta{ }^{13} \mathrm{C}\left[\mathrm{CO}_{2}\right]\right)$ を測定したところー17〜 - $21 \%$ となった（図 $3 \mathrm{e}$ の丸印）。これらの值は, 高温火山ガス, 中低温噴気ガス・温泉ガスなどの 地熱地域に湧出する $\delta{ }^{13} \mathrm{C}\left[\mathrm{CO}_{2}\right] （-10 \sim 0 \%$ : 例 えば, Sano and Marty, 1995）とは大きく異なる。 よって，マグマ揮発性成分の寄与したガスである 可能性は低く，表層で取り込まれた $\mathrm{CO}_{2}$ である可 能性が高い。例えば，堆積物中の有機炭素の関与 が高い $\delta{ }^{13} \mathrm{C}\left[\mathrm{CO}_{2}\right]$ は，このような值をとる (Sano 


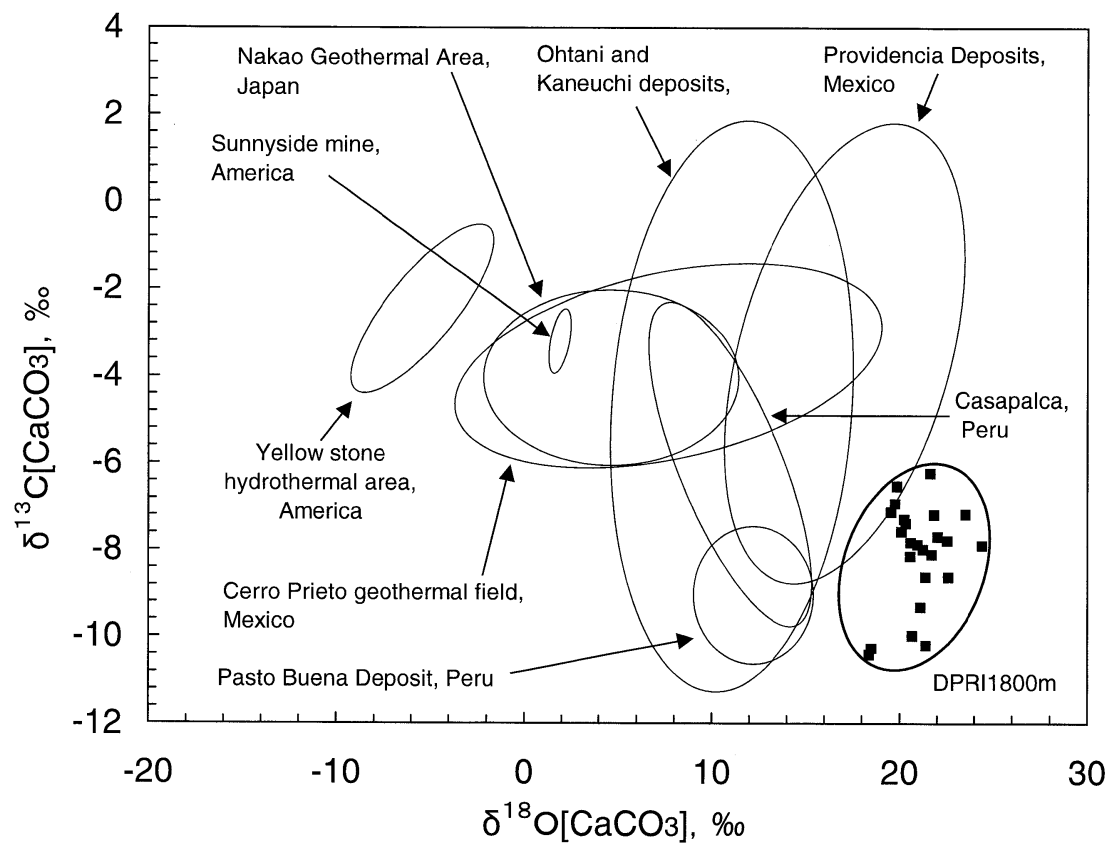

図 5 世界の鉱床および地熱地带に見られるカルサイト脈と DPRI $1800 \mathrm{~m}$ ボーリン グコア中のカルサイト脈の炭素・酸素同位体比との比較.

DPRI 1800 m 以外の值は, Rye (1966), Landis and Rye (1974), Rye and Sawkins (1974), Casadevall and Ohmoto (1977), Olson (1979), 水谷ほか (1983), Morishita (1990), Sturchio et al. (1990) の值を引用.

Fig. 5 The relationship between $\delta^{13} \mathrm{C}$ and ${ }^{18}{ }^{18}$ of $\mathrm{CaCO}_{3}$ in calcite veins in deposits, mine, and geothermal areas in the world with those of DPRI $1800 \mathrm{~m}$ drilling cores (open circle).

Data are from Rye (1966), Landis and Rye (1974), Rye and Sawkins (1974), Casadevall and Ohmoto (1977), Olson (1979), Mizutani et al. (1983), Morishita (1990), and Sturchio et al. (1990).

and Marty, 1995 ; 佐野, 1996)。淡路島北部に分 布する花崗岩は, 第三紀, および第四紀の堆積岩 によって覆われており，これらの堆積物および現 世の海底堆積物を起源としている可能性が高い。

さらに, $\delta{ }^{13} \mathrm{C}\left[\mathrm{CO}_{2}\right]$ の深度分布を詳しく見る と，図 3e (丸印）に示すように $1660 \mathrm{~m}$ 以浅では $-17 \%$, $1660 \mathrm{~m}$ 以深では - 19〜-21\% \%示し, 破砕の程度が大きく変化する掘削深度約 $1660 \mathrm{~m}$ を境に炭素同位体組成が，2３\%下がることが わかる。

3）カルサイトの炭素・酸素同位体比の深度に よる変化とその值の特徴について

DPRI ボーリングコア中の $\delta{ }^{13} \mathrm{C}\left[\mathrm{CaCO}_{3}\right]$, $\delta{ }^{18} \mathrm{O}\left[\mathrm{CaCO}_{3}\right]$ は，それぞれ $-11 \sim-7 \%, 18 \sim$ $23 \%$ であった。これらの測定值を熱水鉱床および 地熱地帯で測定されたカルサイト脈中の $\delta{ }^{13} \mathrm{C}$ $\left[\mathrm{CaCO}_{3}\right], \delta{ }^{18} \mathrm{O}\left[\mathrm{CaCO}_{3}\right]$ と比較してみた。図 5 に 四角印 (黒色) で示すように地熱地帯等の他地域 のデータとは外れた領域にあることがわかる。 $\delta{ }^{13} \mathrm{C}\left[\mathrm{CaCO}_{3}\right]$ 值は, 他地域と比べて低い值, $\delta{ }^{18} \mathrm{O}\left[\mathrm{CaCO}_{3}\right]$ 值は, 他地域と比べて高い值を示 している。

カルサイトの産状が脈状であることから，亀裂 中を通過する地下水に含まれる炭酸イオンがカ ルシウムイオン $\left(\mathrm{Ca}^{2+}\right)$ と反応し, この亀裂中 で沈殿したものと考えられる。よって， $\delta{ }^{13} \mathrm{C}$ 


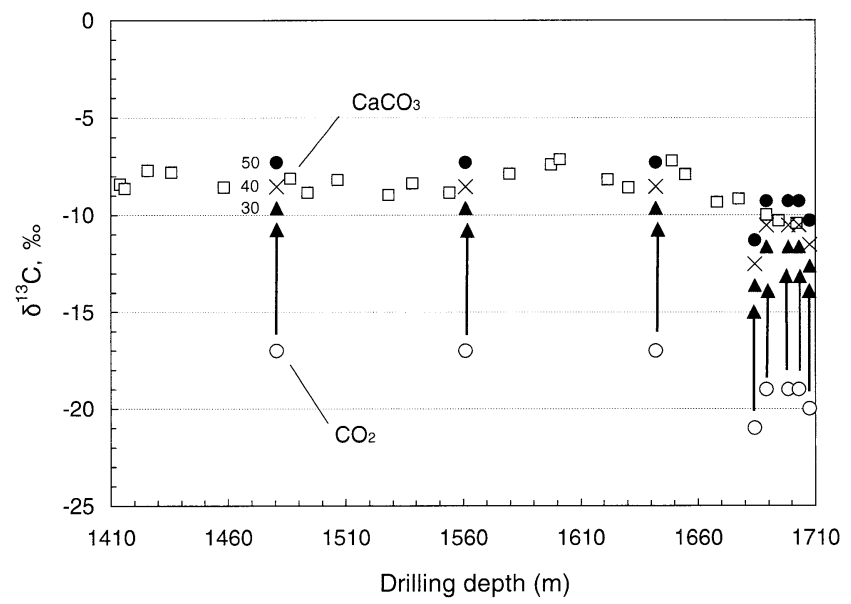

図 6 コア試料中の $\mathrm{CO}_{2}$ ガスの炭素同位体比（○印）とカルサ イトの炭素同位体比（口印）の深度分布 tenn.

山印, ×印, ○印は, $\mathrm{CO}_{2}$ の炭素同位体比 (○印) 加算出さ れた $30,40,50^{\circ} \mathrm{C}$ で同位体平衡にあるカルサイトの炭素同位体 比を示している。

Fig. 6 Carbon isotope ratio of $\mathrm{CO}_{2}$ (open circle) and those of $\mathrm{CaCO}_{3}$ (open square) with depth from core specimens.

Closed triangle, cross, and closed circle indicate calculated values of carbon isotope ratio of $\mathrm{CaCO}_{3}$ in equilibrim with $\mathrm{CO}_{2}$ at the temperature of 30,40 and $50^{\circ} \mathrm{C}$, respectively.

$\left[\mathrm{CaCO}_{3}\right]$ 值が比較的低い值を示すのは, DPRI ボーリングコア中のカルサイトが, 他の地熱地帯 と異なり比較的軽い炭素同位体比をもつ炭酸水 $\left(\mathrm{CO}_{2}\right.$ を溶存する $)$ から沈殿し, ${ }^{18} \mathrm{O}\left[\mathrm{CaCO}_{3}\right]$ 值 が高い值を示すのは，比較的重い酸素同位体比を もつ水から沈殿したことによると推定される。

一方， ${ }^{13} \mathrm{C}\left[\mathrm{CaCO}_{3}\right]$ 值の深度分布（図 $3 \mathrm{e} ） と$ 破砕度の深度分布（図 $3 \mathrm{a}$ ) との間には明確な相 関は見られないが, 最も破砕の進んだ掘削深度 $1660 \mathrm{~m}$ 以深では 1 ～ $2 \%$ 同位体比が下がってい るのが明瞭に見られる。先述したように, 同様の 傾向が $\delta{ }^{13} \mathrm{C}\left[\mathrm{CO}_{2}\right]$ の深度分布にも見られた。 $\mathrm{CO}_{2}$ とカルサイトの関係についての詳細は後述する。

\section{IV. 考察}

1）カルサイトと $\mathrm{CO}_{2}$ の炭素同位体比から推定 した破砕帯シール温度の推定

${ }_{\delta}{ }^{13} \mathrm{C}\left[\mathrm{CO}_{2}\right]$ と $\delta{ }^{13} \mathrm{C}\left[\mathrm{CaCO}_{3}\right]$ の染度分布は,
図 $3 \mathrm{e}$ に示すように $1660 \mathrm{~m}$ 以深でどちらもその值 が低くなるなど，関連が深いように見える。そこ で, 溶存 $\mathrm{CO}_{2}$ ガスとカルサイトの関係について考 えてみる。

$\mathrm{CO}_{2}$ は, $\mathrm{H}_{2} \mathrm{O}$ を介してカルサイトと炭素同位体 交換をする。 $\mathrm{CaCO}_{3}-\mathrm{CO}_{2}$ 間の炭素同位体分別の 温度依存性は次のように確立している（Bottinga， 1968)。

$$
\begin{aligned}
& 1000 \ln \alpha \mathrm{c}\left[\mathrm{CaCO}_{3}-\mathrm{CO}_{2}\right]=\delta{ }^{13} \mathrm{C}\left[\mathrm{CaCO}_{3}\right] \\
& \quad-\delta{ }^{13} \mathrm{C}\left[\mathrm{CO}_{2}\right] \\
& =-2.4612+\left(7.6663 \times 10^{3} / \mathrm{T}\right) \\
& \quad-\left(2.9880 \times 10^{6} / \mathrm{T}^{2}\right)
\end{aligned}
$$

ボーリングコアから採取された溶存 $\mathrm{CO}_{2}$ ガスの $\delta^{13} \mathrm{C}\left[\mathrm{CO}_{2}\right]$ と, $30^{\circ} \mathrm{C}, 40^{\circ} \mathrm{C}, 50^{\circ} \mathrm{C}$ において炭素 同位体平衡にある $\delta{ }^{13} \mathrm{C}\left[\mathrm{CaCO}_{3}\right]$ の值を上式によ り算出した。その值を図 6 にプロットしてみる。 
すると，実測した $\delta{ }^{13} \mathrm{C}\left[\mathrm{CaCO}_{3}\right]$ と ${ }^{13} \mathrm{C}\left[\mathrm{CO}_{2}\right]$ から算出された $40^{\circ} \mathrm{C} に$ に抒り $\delta{ }^{13} \mathrm{C}\left[\mathrm{CaCO}_{3}\right]$ の值 とは，1660 m を境にした同位体比の変化も含め てほぼ一致することがわかった。 ${ }^{13} \mathrm{C}\left[\mathrm{CO}_{2}\right]$ の測 定誤差が士 $1 \%$ であることを考えると, $\mathrm{CaCO}_{3}$ は $30 \sim 50^{\circ} \mathrm{C}$ の温度範囲内で形成されたと推定でき る。ガスおよびカルサイト採取深度（1410～ $1710 \mathrm{~m}$ ）の地温は, 孔内検層デー夕によると 44 〜 $49^{\circ} \mathrm{C}$ であるから， $\delta{ }^{13} \mathrm{C}\left[\mathrm{CaCO}_{3}\right]$ と $\delta{ }^{13} \mathrm{C}\left[\mathrm{CO}_{2}\right]$ が炭素同位体平衡にあったと仮定すると, カルサ イトは地温に近い温度で,つまり現在の場所で形 成され亀裂をシールしたと考えられる。

一方, $1660 \mathrm{~m}$ 以浅と以深で $\delta{ }^{13} \mathrm{C}\left[\mathrm{CaCO}_{3}\right]$, $\delta^{13} \mathrm{C}\left[\mathrm{CO}_{2}\right]$ の值が $2 \sim 3 \%$ 程異なるのは何故だろ うか。この破砕帯中を流れていた流体が $\mathrm{CaCO}_{3}$ を沈殿させつつ, 破砕が進行していない周囲の亀 裂中に拡散し, 同様にカルサイトを沈殿させて いったとすると, 破砕带からその周辺部に向かっ て $\delta{ }^{13} \mathrm{C}\left[\mathrm{CaCO}_{3}\right]$ 值は低くなる。ところが破砕带 である $1660 \mathrm{~m}$ 以深で逆に低くなっている。この 事実は, 破砕带内から流体が拡散したことによっ て, 同位体比が変化したことを示すものではない。 つまり, 破砕带内外で, カルサイト脈を形成し た流体の性質が異なっていたことを示している。

\section{2) $\mathrm{CO}_{2}$ あるいは $\mathrm{HCO}^{3-}$ を運んだ $\mathrm{H}_{2} \mathrm{O}$ の起源}

カルサイトの $\delta{ }^{18} \mathrm{O}$ の測定結果と深度との関係 を図 7 に示す。バラつきは少なく, 直線的に変化 しているのが見える。前節で, $\mathrm{CaCO}_{3}$ は溶存 $\mathrm{CO}_{2}$ とガス採取深度の地温に近い低温環境で炭素同 位体平衡に達していることが判明したと述べ た。よって, カルサイトと $\mathrm{H}_{2} \mathrm{O}$ も地温に近い温度 で酸素同位体平衡に達していると仮定し， $\delta{ }^{18} \mathrm{O}$ $\left[\mathrm{CaCO}_{3}\right]$ 值から $\mathrm{CO}_{2}$ または $\mathrm{HCO}^{3-}$ を運んできた $\mathrm{H}_{2} \mathrm{O}$ の酸素同位体組成を算出し, その起源につい て考察する。 $\mathrm{CaCO}_{3}-\mathrm{H}_{2} \mathrm{O}$ 間の酸素同位体分別の 温度依存性は次式のように確立している（O'Neil et al., 1969)。

$$
\begin{aligned}
& 1000 \ln \alpha \mathrm{c}\left[\mathrm{CaCO}_{3}-\mathrm{H}_{2} \mathrm{O}\right]=\delta{ }^{18} \mathrm{O}\left[\mathrm{CaCO}_{3}\right] \\
& \quad-\delta{ }^{18} \mathrm{O}\left[\mathrm{H}_{2} \mathrm{O}\right] \\
& =2.78\left(10^{6} \mathrm{~T}^{-2}\right)-2.89
\end{aligned}
$$

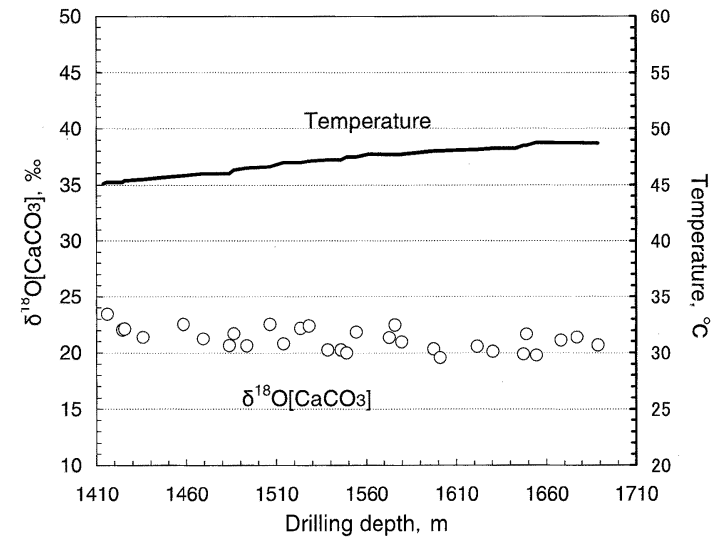

図 7 DPRI $1800 \mathrm{~m}$ ボーリングコア中のカルサイ 卜脈の酸素同位体比（○印）と物理検層から 得られた温度デー夕 (黒線) の深度分布.

Fig. 7 Oxygen isotope ratios of calcite (open circle) in DPRI $1800 \mathrm{~m}$ drilling cores and temperature (solid line) from geophysical well logging results with depth.

よって, カルサイトが，コア採取深度の地温 $\left(44 \sim 49^{\circ} \mathrm{C}\right)$ で形成され, 酸素同位体平衡に達し ていると仮定し, カルサイトを沈殿させた水の $\delta{ }^{18} \mathrm{O}\left[\mathrm{H}_{2} \mathrm{O}\right]$ を（2）式から算出した。その結果, $\delta{ }^{18} \mathrm{O}\left[\mathrm{H}_{2} \mathrm{O}\right]$ 值は, $-1.8 \sim-5.5 \%$ の範囲をとるこ とがわかった。

地表水・浅層地下水の酸素同位体比の地理的分 布を見ると淡路島のそれは $-7 \sim-8 \%$ である (Mizota and Kusakabe, 1994)。

算出された $\delta{ }^{18} \mathrm{O}\left[\mathrm{H}_{2} \mathrm{O}\right]$ 值の測定結果は, 地表 水・浅層地下水の酸素同位体比に比べ，比較的高 い值を示し，重い酸素同位体組成をもつ水から力 ルサイトが形成されたことを示唆している。重い 酸素同位体組成をもつことで知られている水 は, 深部熱水および海水 $(0 \%$ \% $)$ である（松葉谷, 1991）。このどちらかがカルサイトの沈殿に寄与 した可能性が考えられる。通常, 深部熱水が湧出 する地域では，これに付随する $\delta{ }^{13} \mathrm{C}\left[\mathrm{CO}_{2}\right]$ も高い 值を示す。しかし, DPRI $1800 \mathrm{~m}$ 孔ボーリングコ アから採取された溶存炭酸ガスの炭素同位体組成 は地熱地带に湧出する炭素同位体組成と異なるこ とは，III章 2) で述べた。よって，カルサイトを 
沈殿させた水が深部熱水であることは考えにくい。 つまり, DPRI $1800 \mathrm{~m}$ 孔ボーリングコア中のカル サイトを沈殿させた水は, 海水を多量に含んだ水 である可能性が高い。同じくUeda et al. (1999) は，地質調査所によって掘削されたボーリングコ ア中の炭酸塩の酸素同位体比を測定した結果，同 様の結論を得ている。

ただし， $\delta{ }^{18} \mathrm{O}\left[\mathrm{CaCO}_{3}\right]$ 值は，深度が深くなる につれ全体的に減少している。この理由として, 地温勾配を反映して同位体組成が変化したことが 考えられる。しかし，孔内検層による温度勾配 $\left(45 \sim 50^{\circ} \mathrm{C}\right)$ から理論的に求められる酸素同位体 比変動幅（約 $0.7 \%$ ） と実測同位体比変動幅（約 2.5\%o）は一致せず，原因は不明である。

\section{V. ま と}

本論では, 野島断層破砕帯から得られたコア中 の $\mathrm{CO}_{2}$ およびカルサイト脈の炭素, 酸素の同位体 比を測定し，以下の点を明らかにした。

1. 岩石の破砕が比較的進行した深度における カルサイト充填亀裂の傾斜角は, 非破砕部に比べ 高角のものが卓越している。野島断層の傾斜角は 高角であることから破砕帯における高角の炭酸塩 脈形成が，断層運動に関連していると考えられる。

2. $\delta{ }^{13} \mathrm{C}\left[\mathrm{CO}_{2}\right]$ と $\delta{ }^{13} \mathrm{C}\left[\mathrm{CaCO}_{3}\right]$ の深度分布パ ターンは，ほぼ致していた。これらが炭素同位 体平衡にあると仮定すると, $30 \sim 50^{\circ} \mathrm{C}$ において カルサイト脈が形成されたと推定された。さらに, これらの沈殿過程に寄与した流体は, カルサイト の酸素同位体比の測定結果から, 海水と天水の混 合流体である可能性が高い。つまり，野島断層帯 に見られるカルサイト脈は, 現在の地温条件で, 現在地下に存在する水から沈殿したと言える。

3. 野島断層破砕帯外縁部の断層浅部（1410 $1710 \mathrm{~m} ）$ では, $\mathrm{CO}_{2}$ ガスはカルサイト脈形成に寄 与し, 破砕帯をシールさせる断層帯回復過程の一 端を担っていたと考えられる。

\section{謝 辞}

京都大学防災研究所 (現名古屋大学) の安藤雅孝教授 には，コア利用の機会を与えていただいた。 $\mathrm{CO}_{2}$ の炭素 同位体比分析に当たっては, 東京大学地殼化学教室の 野津憲治教授，佐藤雅則氏にご指導いただいた。また， ボーリング現場では, 住鉱コンサルタント株式会社の 川西氏, 西岡氏, 植木氏をはじめ同社の皆様に大変お世 話になった。また，本論を作成するに当たって抢 2 人の 査読者には，有意義なコメントをいただいた。ここにお 礼を申し上げます。

\section{文献}

Ando, M. (2001): Geplogical and geophysical studies of the Nojima Fault from drilling: An outline of the Nojima fault zone probe. The Island Arc, 10, 206-214.

新井崇史・奥澤 保 - 塚原弘昭 (1998): 野島断層小倉 $1800 \mathrm{~m}$ 孔ボーリングコアから抽出したガスの化学成 分および炭素同位体比から推定した断層帯中のガスの 挙動. 月刊地球, 号外, 21, 165-170.

Arai, T., Okusawa, T. and Tsukahara, T. (2001): Behavior of gases in the Nojima Fault Zone revealed from the chemical composition and isotope ratio of gases extracted from DPRI 1800 $\mathrm{m}$ drill core. The Island Arc, 10, 430-438.

Bottinga, Y. (1968): Calculation of fractionation factors for carbon and oxygen isotopic exchange in the system calcite-carbon dioxide-water. $J$. Phys. Chem., 72, 800-808.

Casadevall, T. and Ohmoto, H. (1977): Sunnyside mine, Eureka mining district, San Juan County, Colorado: Geochemistry of gold and base metal ore formation in the volcanic environment. Econ. Geol., 72, 1285-1320.

Epstein, S., Graf, D. and Degens, E.T. (1964): Oxygen Isotope Studies on the Origin of Dolomites. Isotope and Cosmic Chemistry, Amsterdam : North Holland Publ. Comp.

Fujimoto, K., Tanaka, H., Higuchi, T., Tomida, N., Ohtani, T. and Ito, H. (2001): Alteration and mass transfer inferred from the Hirabayashi GSJ drill penetrating the Nojima fault, Japan. The Island Arc, 10, 401-410.

小林健太・福地龍郎・長谷部徳子・林 愛明 $\cdot$ 丸山 正・松田達生・村田明広・重富素子 · 島田耕史 · 竹村 恵二・田中秀実・田中菜摘・富田直人 ·豊田宗則 - 宇 田進一・山北 聡 (1999): 野島断層 $1800 \mathrm{~m}$ 孔掘削コ アに見られる破砕帯外縁部の産状. 地質学雑誌，10, XVI-XVII.

Landis, P.G. and Rye, O.R. (1974): Geologic, fluid inclusion, and stable isotope studies of the Pasto Buena tungsten-base metal ore deposit, nothern Peru. Econ. Geol., 69, 1025-1037. 
松葉谷 治 (1991): 熱水の地球化学. 裳華房.

McCrea, J.M. (1950): On the isotopic chemistry of carbonates and a paleotemperature scale. $J$. Chem. Phys., 18, 849-857.

Mizota, C. and Kusakabe, M. (1994): Spatial distribution of $\delta \mathrm{D}-\delta{ }^{18} \mathrm{O}$ values of surface and shallow groundwaters from Japan, south Korea and east China. Geochem. J., 28, 387-410.

水谷義彦・秋山伸一 - 木村美紀夫 - 日下部 実・佐竹

洋・且井和人・前田伊通子 (1983): 岐阜県中尾地域の 地熱調査井 54-NK-1 における岩石変質と変質鉱物の 同位体地球化学. 日本地熱学会誌，5(2)，121-138.

水野清秀・服部 仁·寒川 旭・高橋 浩 (1990): 明石 地域の地質. 地域地質研究報告 (5万分の 1 地質図幅), 地質調查所, 21-29.

Morishita, Y. (1990): Fluid evolution and geobarometry on the Ohtani and Kaneuchi tungstenquartz vein deposits, Japan: Oxygen and carbon isotopic evidence. Mineralium Deposita, 26, 4050 .

Murata, A., Takemura, K., Miyata, T. and Lin, A. (2001): Quaternary vertical offset and average slip rate of the Nojima fault on Awaji Island, Japan. The Island Arc, 10, 360-367.

Olson, E.R. (1979): Oxygen and carbon isotopes studies of calcite from the Cerro Preito geothermal field. Geothermics, 8, 245-251.

O'Neil, R.J., Clayton, R.N. and Mayeda, T.K. (1969): Oxygen Isotope Fractionation in Divalent Metal Carbonates. J. Chem. Phys., 51, 5547-5558.

Rye, O.R. (1966): The carbon, hydrogen, and oxygen isotopic composition of the hydrothermal fluids responsible for the lead-zinc deposits at Providencia, Zacatecas, Mexico. Econ. Geol., 61,
1399-1427.

Rye, O.R. and Sawkins, J.F. (1974) : Fluid inclusion and stable isotope studies on the Casapalca Ag$\mathrm{Pb}-\mathrm{Zn}-\mathrm{CU}$ deposit, Central Andes, Peru. Econ. Geol., 69, 181-205.

佐野有司 (1996):ヘリウム・炭素同位体比からみマグマ 起源ガスと地殼物質との相互作用. 地質学論集， 46 , 83-90.

Sano, Y. and Marty, B. (1995): Origin of carbon in fumarolic gas from island arcs. Chemical Geology (Isotope Geoscience Section), 119, 265-274.

Sharma, T. and Clayton, R.N. (1965): Measurement of ${ }^{18} \mathrm{O} /{ }^{16} \mathrm{O}$ ratios of total oxygen of carbonates. Geochim. Cosmochim. Acta, 29, 13471353.

Sturchio, N.C., Keith, T.E. and Muehlenbachs, K. (1990): Oxygen and carbon isotope ratios of hydrothermal minerals from Yellowstone drill cores. J. Volcano. Geotherm. Res., 40, 23-37.

Tadokoro, K., Ando, M. and Nishigami, K. (2000): Induced earthquakes accompanying the water injection experiment at the Nojima fault zone, Japan: Seismicity and its migration. J. Geophys. Res., 105, 6089-6104.

角皆 潤 (1997): 海洋におけるメタンプルームの炭素安 定同位体比測定. 月刊地球，号外，18，93-98.

Ueda, A., Kawabata, A., Fujimoto, K., Tanaka, H., Tomita, N., Ohtani, T. and Ito, H. (1999): Isotopic study of carbonates in Nojima fault cores. Proceedings of the International Workshop on the Nojima Fault Core and Borehple Dataanalysis, 127-132.

(2003 年 9 月 10 日受付, 2003 年 12 月 25 日受理) 